\title{
Perbedaan Gender Dalam Sikap Entrepreneur Mahasiswa Pendidikan Biologi
}

\author{
Agus Muliadi \\ Pendidikan Biologi, FSTT, Universitas Pendidikan Mandalika \\ E-mail: agusmuliadi@ikipmataram.ac.id
}

\begin{abstract}
Abstrak: Tujuan penelitian ini adalah untuk mengetahui (1) deskripsi sikap entrepreneur mahasiswa berdasarkan gender; (2) perbedaan sikap entrepreneur antara mahasiswa pria dan wanita. Penelitian ini merupakan penelitian ex post facto dengan pendekatan deskriptif kuantitatif dan deskriptif komparatif. Sampel penelitian ini adalah mahasiswa Pendidikan Biologi Fakultas Sains, Teknik, dan Terapan Universitas Pendidikan Mandalika sebanyak 56 orang yang ditentukan dengan teknik purposive sampling. Instrumen yang digunakan adalah angket tertutup tentang sikap entrepreneur dengan skala likert dan divalidasi ahli. Teknik analisis data yang digunakan yaitu statistik deskriptif dan statistik inferensial uji t (independent simple test) dan dibantu dengan software SPSS 16 for windows. Hasil penelitian ini adalah (1) sikap entrepreneur mahasiswa berjenis kelamin pria memiliki rata-rata sebesar 3,22 kategori Baik; mahasiswa wanita memiliki rata-rata sebesar 3,10 dengan kategori Baik; (2) hasil uji t (independent simple test) menunjukkan bahwa nilai signifikansi sebesar 0,837 lebih kecil dari nilai alpha pengujian 0,05 $(<0,05)$, sehingga dapat disimpulkan bahwa tidak ada perbedaan sikap entrepreneur yang signifikan antara mahasiswa pria dan wanita.
\end{abstract}

Kata kunci: gender, sikap, entrepreneur

\section{PENDAHULUAN}

Indonesia sebagai salah satu negara berkembang yang aktif mendorong warganya, terutama generasi muda untuk berwirausaha dengan mencanangkan Gerakan Nasional Kewirausahaan pada bulan Februari 2011 (Setyawan, 2016). Ketersediaan lapangan kerja saat ini tidak sesuai dengan jumlah lulusan pada setiap level pendidikan di Indonesia, sehingga menyebabkan tingginya angka pengangguran. Merujuk pada data publikasi Badan Pusat Statistik (BPS) pada bulan Mei 2020 bahwa Tingkat Pengangguran Terbuka (TPT) di Indonesia sebesar 4,99\% pada Februari 2020 turun dibandingkan Februari 2019 sebesar 5,01. Tingkat Pengangguran Terbuka (TPT) lulusan perguruan tinggi yaitu Diploma I,II,III sebesar 6,76 dan Universitas sebesar 5,73 (BPS, 2020). Data ini menunjukkan bahwa lulusan perguruan tinggi belum siap sepenuhnya untuk mandiri dalam membangun pekerjaan dan karir (job creator), tetapi masih memiliki pola pikir pencari kerja (job seeker).

Susetyo \& Lestari (2014) menjelaskan bahwa dalam setiap tahun, dari sekitar 3.355 universitas yang beroperasi di Indonesia, dapat menghasilkan lebih dari 339.000 lulusan sarjana untuk memasuki pasaran tenaga kerja.
Oleh sebab itu, persaingan untuk mendapatkan pekerjaan pada suatu instansi menjadi semakin meningkat secara tajam. Kondisi keterbatasan peluang pekerjaan ini menjadi salah satu pemicu utama bagi para calon lulusan universitas untuk mengembangkan kemandiriannya dalam membangun karir (job creator), salah satunya pada bidang wirausaha/entrepreneur.

Pembangunan pendidikan tinggi di Indonesia pada era globalisasi ini diharapkan untuk menghasilkan lulusan yang kreatif, inovatif, produktif, handal, berkualitas dan siap bersaing di berbagai bidang kehidupan (Fatimah, 2013; Primandaru, 2017). Menurut Porter (1997) (dalam Wahyuni dan Hidayati, 2017), perguruan tinggi memerlukan kebijakan pengembangan berbasis masyarakat luas (Broad Based Education) dan berorientasi pada kecakapan hidup (life skill). Perguruan tinggi diharapkan untuk mengembangkan kurikulum dan pembelajaran yang tidak hanya berorientasi pada keilmuan semata, namun juga dapat memfasilitasi kecakapan hidup (life skill) bagi lulusannya. Setiap lulusan perguruan tinggi diharapkan memiliki kompetensi tambahan yang dapat menopang kecakapan hidupnya. Kompetensi kewirausahaan (entrepreneur) diyakini efektif 
untuk meningkatkan kemandirian seseorang, sehingga diperlukan adanya pembelajaran kewirausahaan diterapkan dalam kurikulum perguruan tinggi. Pembelajaran kewirausahaan dapat merubah persepsi, sikap dan prilaku mahasiswa untuk memiliki motivasi kuat dalam menciptakan kreativitas dan inovasi demi terwujudnya wirausaha handal (Supeni dan Efendi, 2017). Pemerintah secara resmi menganjurkan pendidikan tinggi untuk dapat mengintegrasikan pembelajaran kewirausahaan (entrepreneur) dalam kurikulum dan pembelajarannya, sehingga dapat dihasilkan lulusan yang kompeten di bidang entrepreneur. Lulusan yang memiliki sikap dan keterampilan wirausaha (entrepreneur) diyakini memiliki kecakapan hidup dan kemandirian yang lebih baik serta kompetitif. Hal itu sesuai dengan pendapat Agusti, (2017) yang menyatakan bahwa pentingnya memiliki sikap wirausaha (entrepreneur) karena orang yang memiliki kemampuan tetapi tidak memiliki kemauan dan orang yang memiliki kemauan tetapi tidak memiliki kemampuan, keduanya tidak akan menjadi seorang wirausahawan yang sukses.

Sejumlah perguruan tinggi di Indonesia mencanangkan kewirausahaan sebagai bagian dalam program akademik dengan melibatkan matakuliah tertentu hingga merancang kurikulum untuk menyelenggarakan program pendidikan kewirausahaan secara penuh (Setyawan, 2016). Kurikulum Program Studi Pendidikan Biologi Universitas Pendidikan Mandalika (UNDIKMA) telah memasukkan kewirausahaan menjadi salah satu matakuliah yang wajib ditempuh oleh mahasiswa. Keberadaan matakuliah kewirausahaan menunjukkan komitmen awal yang cukup baik untuk mengembangkan pengetahuan, sikap, minat, dan keterampilan kewirausahaan (entrepreneur) bagi setiap lulusannya.

Pelaksanaan pendidikan kewirausahaan diharapkan dapat memfasilitasi mahasiswa dan lulusannya secara optimal untuk memiliki pengetahuan, sikap, dan minat entrepreneur. Pengetahuan yang diperoleh dalam pembelajaran kewirausahaan akan mempengaruhi terbentuknya sikap dan minat entrepeneur mahasiwa (Muliadi, 2020; Hattab, 2014). Gender memiliki peran untuk memoderasi pengaruh pengetahuan terhadap sikap dan minat entrepreneur (Setyawan, 2016). Sedangkan Wongnaa \& Seyram (2014) menyatakan bahwa faktor gender berpengaruh positif signifikan terhadap keputusan mahasiswa untuk berwirausaha setelah mereka lulus. Gender merupakan variabel produktif yang dapat digunakan untuk mengetahui suatu informasi. Adanya perbedaan dasar biologis antara mahasiswa laki-laki dan perempuan yang memungkinkan mereka mengembangkan sikap dan prilaku yang berbeda (Bae et al., 2014). Oleh sebab itu, diperlukan adanya pemetaan untuk mengetahui perbedaan gender dalam sikap entrepreneur mahasiswa Pendidikan Biologi.

\section{METODE}

Penelitian ini merupakan penelitian ex post facto dengan pendekatan deskriptif kuantitatif dan deskriptif komparatif. Penelitian ex post facto adalah untuk meneliti hubungan sebab akibat yang tidak dimanipulasi atau tidak diberikan perlakukan oleh peneliti, namun peneliti hanya merekam data dari kegiatan yang sudah terjadi. Kajian deskriptif kuantitatif digunakan untuk mendeskripsikan nilai sikap entrepreneur mahasiswa Pendidikan Biologi, sedangkan deskriptif komparatif digunakan untuk mendeskripsikan perbedaan gender dalam sikap entrepreneur mahasiswa (Ibnu, 2003; Arikunto, 2006; Singarimbun, 2006).

Penelitian ini menggunakan sampel 56 mahasiswa Pendidikan Biologi FSTT Undikma yang ditentukan dengan teknik purposive sampling. Intrumen yang digunakan adalah angket tertutup dengan jawaban sikap yang berdegradasi sesuai skala likert. Instrumen sikap entrepreneur yang diukur dalam penelitian ini mengacu pada indikator sikap entrepreneur yang dikembangkan Alma (dalam Agusti, 2017) yaitu percaya diri, berani mengambil resiko, kepemimpinan, kreatif dan inovatif, tekun, bertanggungjawab, berorientasi ke masa depan. Angket disusun dan diuji validitasnya oleh para pakar (expert) (Muliadi et al., 2019).

Analisis data penelitian yang digunakan adalah statistik deskriptif dan statistik inferensial. Statistik deskriptif digunakan 
untuk mendeskripsikan sikap entrepreneur mahasiswa. Rata-rata data sikap entrepreneur dilakukan konversi dalam bentuk kategori dengan mengacu pada kategori penilaian sikap yang dikembangkan Kementerian Pendidikan dan Kebudayaan tahun 2013 (Muliadi, 2020) yaitu:

Tabel 1. Konversi skor sikap entrepreneur mahasiswa

\begin{tabular}{ll}
\hline Rata-rata skor & Interpretasi \\
\hline $3,51-4,00$ & Sangat Baik \\
$2,51-3,50$ & Baik \\
$1,51-2,50$ & Cukup Baik \\
$1,00-1,50$ & Kurang Baik \\
\hline
\end{tabular}

Statistik inferensial yang digunakan untuk mengetahui perbedaan gender dalam sikap entrepreneur mahasiswa. Teknik analisis yang digunakan adalah uji-t pada taraf signifikansi $5 \%$, dengan rumusan hipotesis statistik yaitu $\mathrm{H} 0: \mu 1=\mu 2$ (tidak ada perbedaan signifikan sikap entrepreneur antara mahasiswa laki-laki dan perempuan) dan $\mathrm{H} 1: \mu 1 \neq \mu 2$ (ada perbedaan signifikan sikap entrepreneur antara mahasiswa laki-laki dan perempuan). Jika hasil analisis signifikan atau $p$-value uji korelasi lebih kecil dari 0,05, maka H0 ditolak dan H1 terima atau sebaliknya. Analisis data dibantu dengan software SPSS 16 for windows.

\section{HASIL DAN PEMBAHASAN}

Instrumen untuk mengukur sikap kewirausahaan (entrepreneur) diberikan kepada mahasiswa Pendidikan Biologi Universitas Pendidikan Mandalika (UNDIKMA) sebanyak 56 orang. Instrumen dikembangkan merujuk pada indikator sikap entrepreneur yang diadaptasi dari teori sikap entrepreneur yang dikembangkan teori Alma (dalam Agusti, 2017) yaitu percaya diri, berani mengambil resiko, kepemimpinan, kreatif dan inovatif, tekun, bertanggungjawab, berorientasi ke masa depan. Hasil uji validitas oleh para pakar (expert) sebagai validator menunjukkan bahwa instrumen sikap entrepreneur secara kualitatif dinyatakan valid.

Deskripsi data hasil pengukuran sikap entrepreneur mahasiswa berdasarkan gender atau jenis kelamin disajikan pada tabel 2 berikut ini:
Tabel 2. Data sikap entrepreneur mahasiswa

\begin{tabular}{cccc}
\hline Jenis Kelamin & Total Skor & Rata-Rata & Kategori \\
\hline Pria & 61,17 & 3,22 & Baik \\
Wanita & 114,67 & 3,10 & Baik \\
\hline
\end{tabular}

Deskripsi data hasil pengukuran pada tabel di atas menunjukkan data sikap entrepreneur mahasiswa berdasarkan gender dengan rincian bahwa mahasiswa Pendidikan Biologi berjenis kelamin Pria memiliki total skol sebesar 61,17 dan rata-rata sebesar 3,22 dengan kategori Baik, sedangkan mahasiswa Pendidikan Biologi berjenis kelamin Wanita memiliki total skor sebesar 114,67 dan rata-rata sebesar 3,10 dengan kategori Baik. Deskripsi data dipertegas dalam sajian gambar di bawah ini.

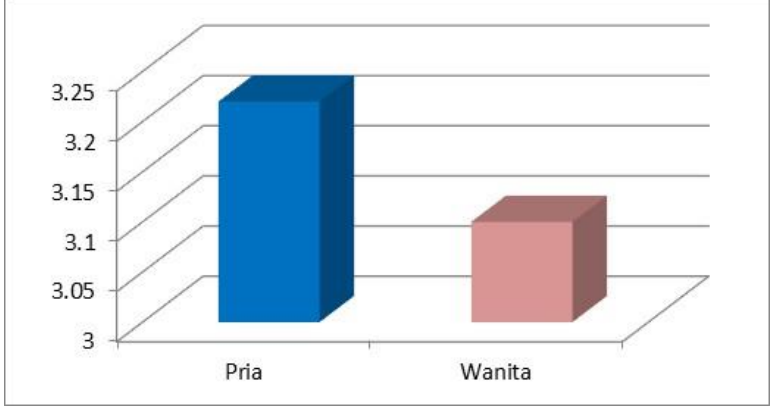

Gambar 1. Rata-rata sikap entrepreneur mahasiswa berdasarkan gender

Data sikap entrepreneur mahasiswa dianalisis menggunakan statistik parametrik, dengan syarat varians data homogen. Hasil uji homogenitas disajikan pada tabel 3 berikut ini. Tabel 3. Hasil analisis homogenitas

\begin{tabular}{|c|c|c|c|}
\hline \multirow{2}{*}{ Varians } & \multirow{2}{*}{$N$} & \multicolumn{2}{|c|}{ Homogenitas } \\
\cline { 3 - 4 } & $\begin{array}{c}\text { Levenes } \\
\text { Statistic }\end{array}$ & Sig. \\
\hline $\begin{array}{c}\text { Sikap } \\
\text { Entrepreneur }\end{array}$ & 56 & 0,042 & 0,837 \\
\hline
\end{tabular}

Hasil uji homogenitas menunjukkan bahwa varian data homogen dengan nilai signifikansi sebenar 0,837 lebih besar dari nilai alpha pengujian $0,05(>0,05)$.

Uji statistik yang digunakan adalah uji $\mathrm{t}$ (independent sample test) untuk mengetahui signifikansi perbedaan sikap entrepreneur antara mahasiswa pria dan wanita. Hasil uji-t tentang perbedaan gender dalam sikap entrepreneur mahasiswa disajikan pada tabel 4 berikut:

Tabel 4. Hasil uji t (independent sampel test) 


\section{Terakreditasi Peringkat 4 (No. SK: 36/E/KPT/2019)}

\begin{tabular}{|c|c|c|c|c|c|c|}
\hline \multicolumn{2}{|c|}{ Group } & \multicolumn{4}{|c|}{ t-test for Equality for Means } \\
\cline { 4 - 7 } & & $t$ & df & Sig. & Mean diff. \\
\hline $\begin{array}{c}\text { Sikap } \\
\text { Entrepreneur }\end{array}$ & $\begin{array}{c}\text { Equal Variances } \\
\text { Assumed }\end{array}$ & $\begin{array}{c}\text { Pendidikan } \\
\text { Biologi }\end{array}$ & 1,205 & 54 & 0,837 & 0,72119 \\
\hline
\end{tabular}

Hasil uji-t menunjukkan bahwa nilai signifikansi sebesar 0,837 lebih besar dari nilai alpha pengujian $0,05(>0,05)$, sehingga $\mathrm{H}_{1}$ ditolak dan $\mathrm{H}_{0}$ diterima yang artinya bahwa tidak ada perbedaan sikap entrepreneur yang signifikan antara mahasiswa berjenis kelamin pria dan wanita.

Hasil penelitian ini menunjukkan tidak ada perbedaan sikap entrepreneur antara mahasiswa berjenis kelamin pria dan wanita dikarenakan mahasiswa Pendidikan Biologi baik pria maupun wanita sama-sama pembelajaran kewirausahaan sehingga mereka memiliki pengetahuan dan sikap entrepreneur yang sama-sama berkategori baik. Hal ini sesuai dengan hasil penelitian Yunilasari \& Rahardjo (2016) bahwa gender tidak berpengaruh terhadap kemampuan dan minat wirausaha mahasiswa, yang dibuktikan dengan nilai $P$-value sebesar $0,167>\alpha 0,05$ (tidak signifikan). Hasil penelitian lainnya adalah penelitian Damayanti (2013) bahwa tidak ada perbedaan signifikan kemampuan dan minat wirausaha antara mahasiswa laki-laki dan perempuan, yang dibuktikan dengan nilai $P$ value sebesar 0,432> $>0,05$ (tidak signifikan).

Hasil penelitian ini menunjukkan bahwa gender memoderasi pengaruh pengetahuan terhadap sikap entrepreneur mahasiswa Pendidikan Biologi secara sama-sama antara pria dan wanita, sehingga mahasiswa Pendidikan Biologi berjenis kelamin pria dan wanita memiliki sikap entrepreneur yang sama-sama berkategori baik. Sikap entrepreneur dipengaruhi oleh pengetahuan yang dimiliki oleh mahasiswa Pendidikan Biologi (Muliadi, 2020; Setyawan, 2016). Pengetahuan tentang entrepreneur dapat diperoleh dari berbagai sumber seperti pembelajaran kewirausahaan dan pengalaman sehari-hari.

Pembelajaran kewirausahaan akan memberikan penguatan pengetahuan secara terstruktur dan sistematis kepada mahasiswa, sehingga terbentuk mindset dan keterampilan sebagai seorang entrepreneur. Pada akhirnya pengalaman belajar akan merubah persepsi, sikap dan prilaku mahasiswa untuk memiliki motivasi yang kuat dalam menciptakan kreativitas dan inovasi demi terwujudnya wirausaha handal (Supeni \& Efendi, 2017; Sumarsono, 2009). Pendapat lainnya disampaikan bahwa perananan pembelajaran kewirausahaan sangat strategis karena mampu memfasilitasi keterampilan berwirausaha (entrepreneur) dan kecakapan hidup (life skill) secara terintegrasi, terstruktur, sistematis, kontinyu dan kolaboratif dengan pendidikan keluarga. Akhirnya lulusan memiliki kompetensi dan keterampilan sebagai insan yang mandiri dalam persaingan global, kebudayaan dan masyarakat sekitarnya (Fatimah, 2013; Nurseto, 2010; Wahyuni dan Hidayati, 2017; Sonhadji, 2006).

Pembelajaran

kewirausahaan (entrepreneur) dapat membangun mainset dan life skill lulusan secara komprehensif, sehingga memiliki kemandirian dalam menjalankan hidup. Hal ini sesuai dengan pendapat Thomas (dalam Fatimah, 2013) bahwa pembelajaran kewirausahaan (entrepreneur) memfasilitasi mahasiswa untuk mampu menggabungkan kreativitas, inovasi, keahlian manajemen peluang, keberanian menghadapi resiko dan kerja keras untuk membentuk dan memelihara usaha baru. Pembelajaran berbasis entrepreneurship di perguruan tinggi nantinya akan meluluskan alumni dengan kompetensi yaitu keratif, inovatif, produktif, percaya diri; berani mengambil resiko; memiliki jiwa kepemimpinan; yakin; tidak ketergantungan; optimis; tekun; kerja keras (Hantoro, 2005; Nugroho, 2009). Oleh sebab itu, empat pilar pendidikan sangat relevan dalam menjalankan pembelajaran berbasis entrepreneurship yaitu Learning to know (belajar untuk mengetahui kewirausahaan), learning to do (belajar untuk melakukan kegiatan wirausaha), learning to be (belajar untuk menjadi entrepreneur), dan learning to live together (belajar untuk bersama dengan yang lainnya dalam interaksi sosial saat berwirausaha) (Supeni dan Efendi, 2017; Rosmiati, 2015).

Pengembangan sikap entrepreneur mahasiswa Pendidikan Biologi dapat dilakukan melalui integrasi nilai-nilai entrepreneur dalam matakuliah biologi yang memiliki materi relevan seperti Mikrobiologi 
dan Bioteknologi. Pembelajaran biologi berbasis entrepreneur yang disingkat bioentrepreneurship sangat relevan untuk diterapkan di perguruan tinggi sesuai dengan hakekat pembelajaran biologi yang mengutamakan discovery, inquiry, constructivism, contextual dan science, technology, and society. Pembelajaran bioentrepreneurship adalah pembelajaran kontekstual yang memfasilitasi pengalaman belajar dalam mengamati, mengidentifikasi, mengkaji, menganalisis dan memanfaatkan biodiversitas dan bioteknologi untuk menciptakan produk yang mengandung nilai ekonomi. Pembelajaran bioentrepreneurship diharapkan dapat memberikan pengalaman belajar kepada mahasiswa untuk menjadi academic entrepreneurship yang memiliki nilai-nilai seperti mandiri, kreatif, berani mengambil resiko, berorientasi pada tindakan, kepemimpinan, kerja keras, jujur, disiplin, inovatif, tanggung jawab, kerjasama, pantang menyerah, komitmen, realistis, rasa ingin tahu, komunikatif, dan motivasi kuat untuk sukses. Oleh sebab itu, pada pembelajaran bioentrepreneurship, selain untuk menjadikan mahasiswa menguasai kompetensi (materi) yang ditargetkan, juga dirancang dan dilakukan untuk menjadikan mahasiswa mengenal, menyadari/peduli, dan menginternalisasi nilai-nilai kewirausahaan dan menjadikannya perilaku dan keterampilan hidupnya (life skill) (Agusti, 2017; Sudarisman, 2015; Kristianti, 2012; Ulwiyah, 2010; Priyanto, 2009).

\section{KESIMPULAN}

Berdasarkan hasil penelitian dan pembahasan di atas, maka dapat disimpulkan bahwa (1) sikap entrepreneur mahasiswa Pendidikan Biologi berjenis kelamin pria dan wanita sama-sama berkategori Baik. Hal itu sesuai dengan data sikap entrepreneur mahasiswa pria memiliki rata-rata sebesar 3,22 dengan kategori Baik; mahasiswa wanita memiliki rata-rata sebesar 3,10 dengan kategori Baik; (2) Tidak ada perbedaan gender dalam sikap entrepreneur mahasiswa Pendidikan Biologi. Hal itu sesuai dengan hasil uji $\mathrm{t}$ (independent simple test) menunjukkan bahwa nilai signifikansi sebesar 0,837 lebih kecil dari nilai alpha pengujian $0,05(<0,05)$.

\section{DAFTAR PUSTAKA}

Agusti, E. 2017. Pengembangan Handout Pembelajaran IPA berbasis Entrepreneurship untuk Siswa Kelas XI Tata Niaga di Sekolah Menengah Kejuruan. Artikel Skripsi Fakultas Keguruan dan Ilmu Pendidikan Universitas jambi (Tidak diterbitkan).

Arikunto. 2006. Prosedur Penelitian (Suatu

Pendekatan Praktik). Jakarta: Rineka Cipta.

Badan Pusat Statistik. 2020. Keadaan Ketenagakerjaan Indonesia Februari 2020. Jakarta: Berita Resmi Statistik.

Bae, T.J., Qian, S., Miao, C., \& Fiet, J.O. 2014. The Relationship Between Entrepreneurship Education and Entrepreneurial Intentions. Sage Jurnals, 38 (2), 217-254.

Damayanti, N. 2013. Perbedaan Jenis Kelamin terhadap Minat Berwirausaha Mahasiswa Jurusan Pendidikan Ekonomi Universitas Negeri Surabaya. Jurnal Pendidikan Tata Niaga (JPTN), 1 (3), 1-16.

Fatimah, S. 2013. Menumbuhkan Jiwa Wirausaha Muda dalam Pembelajaran Ekonomi. CRIKSETRA: Jurnal Pendidikan dan Kajian Sejarah, 3 (4), 1-9.

Hantoro, S. 2005. Kiat Sukses Berwirausaha, Yogyakarta: Adicita Karya Nusa.

Hattab, H. W. 2014. Impact of Entrepreneurship Education on Entrepreneurial Intentions of University students in Egypt. The Journal of Entrepreneurship, 23(1), $1-18$.

Ibnu. S. 2003. Dasar-Dasar Metodologi Penelitian. Malang: Universitas Negeri Malang.

Kristianti, E.A., Bintari, S.H., \& Ridlo, S. 2012. Pengembangan Perangkat Pembelajaran Bioentrepreneurship Pembuatan Makanan dari Limbah Cair Pengolahan Kedelai. Journal of Innovative Science Education, 1 (1), 112-118.

Muliadi, A. 2020. Sikap Entrepreneur Mahasiswa Pendidikan Biologi. 
Jurnal Ilmu Sosial dan Pendidikan, 4 (3), 286-291.

Muliadi, A., Prayogi, S., Mirawati, B., Azmi, I., \& Verawati, N.N.S.P. 2019. Efek Strategi Konflik Kognitif dalam Pembelajaran berbasis Model Inkuiri terhadap Kemampuan Berpikir Kritis Mahasiswa. Jurnal Prisma Sains, 7 (1), 60-67.

Nugroho, R. 2009. Memahani Latar Belakang Pemikiran Entrepreneurship Ciputra. Jakarta: Elex Media Komputindo.

Nurseto, T. 2010. Pendidikan berbasis

Entrepreneur. Jurnal Pendidikan

Akuntansi Indonesia, 8 (2), 52 - 59

Primandaru, N. 2017. Analisis Faktor-Faktor Yang Berpengaruh Pada Minat Berwirausaha Mahasiswa. Jurnal Economia, 13 (1), 68-78.

Priyanto, S. 2009. Mengembangkan Pendidikan Kewirausahaan di Masyarakat. Jurnal PNFI, 1 (1), 5782.

Rosmiati, D.T.S. 2015. Sikap, Motivasi, dan Minat Berwirausaha Mahasiswa. $J M K, 17$ (1), 21-30.

Setyawan, A. 2016. Apakah Gender Bermakna Pada Model Pembentukan Minat Berwirausaha?. Jurnal Manajemen Teori dan Terapan, 9 (2), 120-127.

Singarimbun, M. 2006. Metode Penelitian Survai (Edisi Revisi). Jakarta Barat: Pustaka LP3ES Indonesia.

Sonhadji, A. 2006. Manajemen Berbasis Sekolah dan Masyarakat. Jakarta: Nimas Multima.

Sudarisman, S. 2015. Memahami hakikat dan Karakteristik Pembelajaran Biologi dalam Upaya Menjawab Tantangan Abad 21 serta Optimalisasi Implementasi Kurikulum 2013. Jurnal Florea, 2 (1), 29-35.

Sumarsono, 2009. Wirausaha. Bandung: Mandar Maju.

Supeni, R.E \& Efendi, M. 2017. Minat Mahasiswa dalam Berwirausaha Perguruan Tinggi Swasta di Kabupaten Jember. Prosiding Seminar Nasional dan Call For Paper Ekonomi dan Bisnis. Jember, 27-28 Oktober 2017: 449-463.
Susetyo, D., \& Lestari, P. S. 2014. Developing Entrepreneurial Intention Model Of University Students: an Empirical Study on University Students in Semarang Indonesia. International Journal of Engineering and Management Sciences, 5 (1), 184196.

Ulwiyah, N. 2010. Integrasi Nilai-nilai Entrepreneurship Dalam Proses Pembelajaran di Kelas Guna Menciptakan Academic Entrepreneur Berkarakter. Makalah pada Program Studi PGMI, Fakultas Agama Islam, Unipdu Jombang (Tidak diterbitkan).

Wahyuni, W.R \& Hidayati, W. 2017. Peran Sekolah dalam Membentuk Keterampilan Wirausaha Berbasis Tauhid di SD Entrepreneur Muslim Alif-A Piyungan Bantul Yogyakarta. MANAGERIA: Jurnal Manajemen Pendidikan Islam, 2 (2), 359-377.

Wongnaa, C.A. \& Seyram, A.Z.K. 2014. Factors Influencing Polytechnic Students Decision to Graduate as Entrepreneurs. Journal of Global Entrepreneurship Research, 2 (2), 113.

Yunilasari, A. \& Rahardjo. 2016. Analisis Pengaruh Faktor Gender dan Lingkungan Keluarga terhadap Minat Berwirausaha Mahasiswa. Diponegoro Journal of Management, 5 (3), 1-11. 